\title{
Towards Urban Energy Management: A Brief Review of China's Recent Transition in Urban Energy Demand
}

\author{
Ali Cheshmehzangi1,2 \\ ${ }^{1}$ Department of Architecture and Built Environment, University of Nottingham Ningbo China, Ningbo, China \\ ${ }^{2}$ Centre for Sustainable Energy Technologies, University of Nottingham Ningbo China, Ningbo, China \\ Email: Ali.Cheshmehzangi@nottingham.edu.cn
}

How to cite this paper: Cheshmehzangi, A. (2020) Towards Urban Energy Management: A Brief Review of China's Recent Transition in Urban Energy Demand. Low Carbon Economy, 11, 1-24.

https://doi.org/10.4236/lce.2020.111001

Received: January 30, 2020

Accepted: March 27, 2020

Published: March 30, 2020

Copyright $\odot 2020$ by author(s) and Scientific Research Publishing Inc. This work is licensed under the Creative Commons Attribution International License (CC BY 4.0).

http://creativecommons.org/licenses/by/4.0/

(c) (i) Open Access

\begin{abstract}
It is widely accepted the lifeblood of urban economy and growth is energy. Urban transport, infrastructure, industry, and dwellings dominate energy consumption in the built environment. Nevertheless, energy efficiency in urban growth is a key factor that is widely questioned and little understood. As a result, this paper aims to question challenging matters of urban growth and energy by reviewing China's recent transition in urban energy demand. This study offers a better understanding of urban energy management and energy demands of rapidly urbanizing countries, by using China as a leading example. Since the 1980s, after the unprecedented rapid urbanization and growth in China, there are major goals to tackle the emerging matters of urban energy management and growing energy demands. These national-level challenges are imposing serious threats to how cities grow and are managed in the coming decade or so. In light of this, and the face of rapid urbanization and urban growth, this paper investigates China's current trends of urban energy management and energy demands. Finally, this paper explores current approaches to urban development in China and will offer an overview of China's requirement to tackle its current energy challenges. The findings of this study are highlighted as part of a brief review of China's recent five-year-plans and are then developed further in the light of what energy targets mean for cities and urban management.
\end{abstract}

\section{Keywords}

Urban Management, Energy Transition, Urban Growth, Urban Energy,

Energy Demand, Transition, Five-Year-Plan (FYP), China,

Urbanization 


\section{Introduction}

In the developing world, and particularly in rapidly developing countries, urban growth is not merely considered the rate of growth of the urban population but embraces economic growth involving both consumption and production (Yusuf \& Saich, 2008; NDRC, 2016). Over the last two decades, the energy consumption and production rates are increasing in China and have been increasing even more during the recent urbanization phase of the new-type urbanization plan (NUP) (Cheshmehzangi, 2016). This transitional phase has made China become the number one crude oil importer in 2017 (S\&P Global Platts, 2017). The energy growth in the household and industrial sector is also seen to be increasing rapidly, which is already evidenced in existing scholarly research. Hence, as the recent projections indicate (Chen et al., 2020; Li et al., 2020; Ma et al., 2020; Su \& Lee, 2020), the process of urban growth is expected to and is likely to continue at a faster pace in the coming one or two decades. For instance, China's carbon emission peak is expected to be around 2030 (Cheshmehzangi, 2016; Elzen et al., 2016; Liu et al., 2017) and this means we are expected to have a continuing intensified urban development and urbanization for at least the next 10 years. This is also identified as a potential perspective for energy-related carbon emissions (Fang et al., 2019) and associated with the 2030 national energy policy targets (Zhang et al., 2020). For the latter, the predictions are for China to enter the phase of a steady decline from 2025 onwards while complying with energy efficiency requirements and energy policy targets (Qi et al., 2013). In fact, as discussed by Zhang et al. (2020) "China has pledged to peak its carbon dioxide $\left(\mathrm{CO}_{2}\right)$ emissions and lower its $\mathrm{CO}_{2}$ intensity by $60 \%-65 \%$ from the 2005 level by 2030 ". This is also believed to put significant pressure on energy structural adjustments to ensure meeting the national target plans by 2030. Yet, in this process, there are major challenges that need to be addressed to achieve sustainable urban growth and better management of urban development and urban areas. In consideration of combined effects from urban growth and energy demands, the dynamics of urban management are either neglected or little-understood in how these impact sustainable urban growth and development. Hence, this study aims to highlight these complexities by providing an overview of what may be a difficult transitional phase from 2020 to 2030.

It is widely recognized that as part of the development process, cities are key players in developing market economies and making economies more viable (Adams, 1994). As cities are identified as the font of innovation (Shearmur, 2012), they also play a major part in decarbonization processes (Cheshmehzangi, 2016) and towards green development. The relationship between innovation and growth is seen in existing scholarly research (Hall 1999; Simmie, 2001; Acs, 2002; van Oort, 2004; Wolfe \& Bramwell, 2008; Duranton, 2011; Komninos, 2011; Krätke, 2011; Devins et al., 2016; Florida et al., 2016). Much of it, however, depends on the organizing capacity (Nijkamp et al., 2010), entrepreneurship in development mode (Xie et al., 2020), and regional creative capacity (Gülümser et al., 2010). Therefore, we can argue that achieving sustainable urban growth de- 
pends on how market economies are related to both consumption and production of the urban population as well as of the built environments. The imbalance that may exist may turn into patterns of excessive consumption or higher production in specific sectors. For instance, this is already visible in growing energy demand in the residential sector. In this respect, we can argue that the energy management of the urban population will remain a major challenge for rapidly urbanizing developing countries like China. The nexus between urbanization and increasing energy demand would mean opportunities for investing in alternative energy use and enhancement of the existing structural systems. To rethink these, we may need to look into the bigger picture of urbanization and its impact on the growing demand for cities and communities, those that undoubtedly put more pressure on urban management issues. Therefore, this requires new methods and systems to overcome any possible growth or development failures that involve issues of energy and energy management. As a result, this explanatory paper discusses urban growth and its implication as part of the process of development. This paper looks into the case of China's urbanization and urban growth and will identify urban energy challenges that require better management and development strategies in the next decade or so. The aim of this study is to provide an overview of this transitional phase that is to shift towards sustainable urban energy management.

\subsection{Urban Growth: Development and Production}

Currently, more than $80 \%$ of the world's population live in less developed regions. Asia and Africa account for $60 \%$ and $14 \%$ of the world population respectively, which are the two highest at a global scale (United Nations, 2009). In the last decade, we have seen increases at the global level, with the highest impact in the context of Asia, such as in countries like China. By 2025, these figures will dramatically change as significant increments in urban growth and urbanization rates are expected to occur in both continents of Asia and Africa (Figure 1). Urbanized areas in both continents are forecast to grow most rapidly, doubling in (urban) population between 2000 and 2030 (UN Population Fund, 2007). This significant demographic change indicates a major shift in the rate of development and production in the coming decades. As part of the process of urbanization, such a major change will ultimately increase the spread of energy demand. It is already evident that many major cities in the developing world are the main economic hubs and developing at a rapid pace. Management of the growing urban population in this context will require considerable and unique approaches to development.

In addition, despite occupying only $3 \%$ of the land surface, cities use more than $75 \%$ of the overall energy consumption of the world and produce $50 \%$ of the global waste; however, they generate $80 \%$ of the global GDP (UNEP, 2012; Cheshmehzangi \& Dawodu, 2019). A number of international agenda (IPCC, 2007; Agenda 21, 2012; World Economic Forum, 2012) have considered comprehensive impact assessments, economic management and sustainable approaches 
Urban Population as Percentage of Total Population

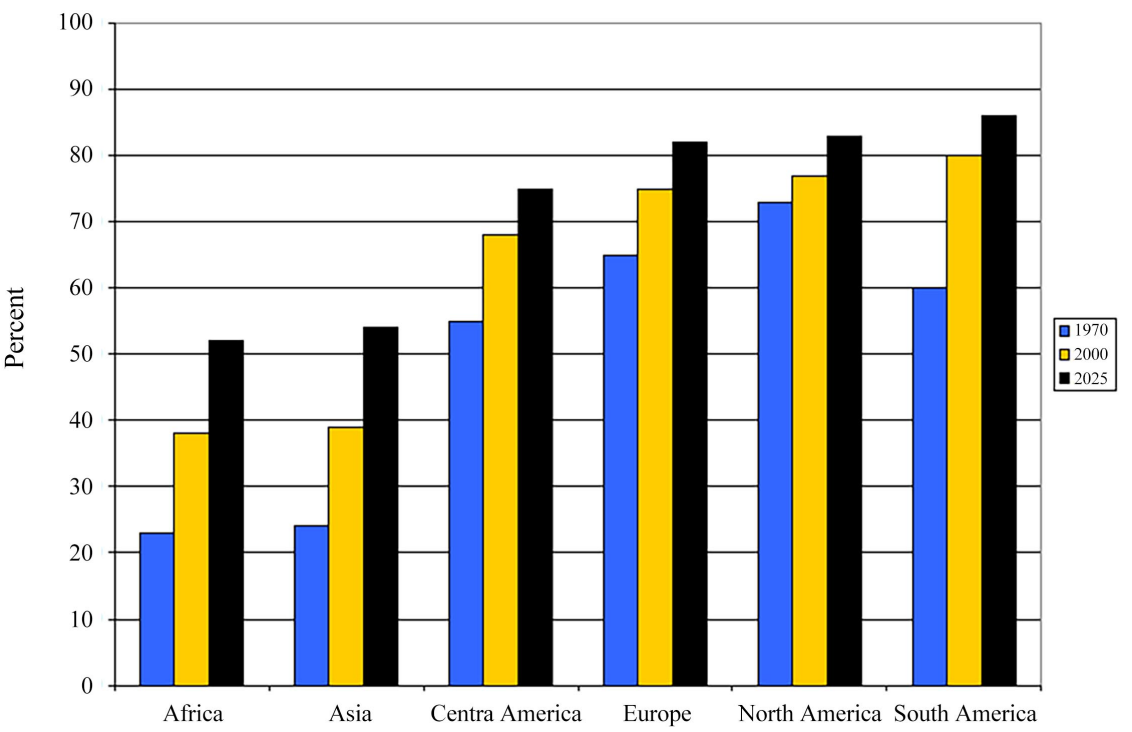

Figure 1. Urban population and the trend of global growth. (Source: Adapted from the United Nations, 2004. World Population Prospects).

to address major urban challenges; one of which is to fulfill social and economic demands, and particularly the energy demand, of the growing urban population. Thus, despite being the great economy generators, cities are mainly considered the main energy consumers. We can then argue that the growing demand and consumption will increase the pressure on how cities may develop and how they can meet the needs of their growing population.

\subsection{Urban Growth: Issues of Demand and Consumption}

In many urban management studies, the crucial impact of energy demand and growth is consumption in the built environment (Keong, 2005; Wolde-Rufael, 2005; Huzayyin \& Salem, 2013; You, 2013; Sheng et al., 2014; Esmaeeli et al., 2015; Akalpler \& Shingil, 2017; Peng et al., 2018; Zhang et al., 2020; Xu \& Wang, 2020). This is substantially reflected through dynamic growth and it often neglects the overall urban economies. In the process of urbanisation and growth, expansion of urban development tends to result in demographic changes resulting in significant impacts to the overall urban management and energy consumption (Table 1). Also, it means the way cities are designed and operate can lead to possible reductions in greenhouse gas emissions and enhancement to energy efficiency; lessening major urban pressures such as poverty and energy demand. Although neglected in current urban studies and debate, there is a great deal of international research into how integrated approaches are developed, implemented and managed for improved energy system performance, legislation and energy efficiency initiatives.

In addition, increased patterns of energy demand and consumption will have further impact on equity and efficiency of urban growth. This can have direct 
Table 1. IEA Key energy statistics 2010 for regional energy use for the understanding of China's position before the $12^{\text {th }}$ FYP (Source: adapted and redrawn from IEA/OECD, Population OECD/World Bank, 2010).

\begin{tabular}{|c|c|c|c|c|c|c|c|c|c|}
\hline \multicolumn{10}{|c|}{ Regional Energy Use (kWh/Capita and TWh) and Growth 1990-2008 (\%) } \\
\hline & \multicolumn{3}{|c|}{ kWh/capita } & \multicolumn{3}{|c|}{$\begin{array}{l}\text { Demographic change/ } \\
\text { Population (Million) }\end{array}$} & \multicolumn{3}{|c|}{$\begin{array}{l}\text { Energy Use } \\
\text { (1000 TWh) }\end{array}$} \\
\hline & 1990 & 2008 & Growth & 1990 & 2008 & Growth & 1990 & 2008 & Growth \\
\hline USA & 89,021 & 87,216 & $-2 \%$ & 250 & 305 & $22 \%$ & 22.3 & 26.6 & $20 \%$ \\
\hline EU-27 & 40,240 & 40,821 & $1 \%$ & 473 & 499 & $5 \%$ & 19.0 & 20.4 & $7 \%$ \\
\hline Middle East & 19,422 & 34,774 & $79 \%$ & 132 & 199 & $51 \%$ & 2.6 & 6.9 & $170 \%$ \\
\hline China & 8839 & 18,608 & $111 \%$ & 1141 & 1333 & $17 \%$ & 10.1 & 24.8 & $146 \%$ \\
\hline Latin America & 11,281 & 14,421 & $28 \%$ & 355 & 462 & $30 \%$ & 4.0 & 6.7 & $66 \%$ \\
\hline Africa & 7094 & 7792 & $10 \%$ & 634 & 984 & $55 \%$ & 4.5 & 7.7 & $70 \%$ \\
\hline India & 4419 & 6280 & $42 \%$ & 850 & 1140 & $34 \%$ & 3.8 & 7.2 & $91 \%$ \\
\hline Others & 25,217 & 23,871 & No data & 1430 & 1766 & $23 \%$ & 36.1 & 42.2 & $17 \%$ \\
\hline The World & 19,422 & 21,283 & $10 \%$ & 5265 & 6688 & $27 \%$ & 102.3 & 142.3 & $39 \%$ \\
\hline
\end{tabular}

or/and indirect impact on pace and quality of development. In his comparison study of two major American cities, discussing energy and urban growth, Platt (1987) referred to the study of energy as a "separate source of growth distinct from other economic factors", meaning that energy plays a major role in improving our knowledge of the process of urbanisation and its implications. This has become more apparent in the context of developing countries as prices of oil and other energy sources rise faster than before. This is alarming for emerging economies as urbanisation and urban growth are both of considerable importance as part of overall development. The major transition of energy consumption and increase in demand will require top-down scale management. We can, therefore, argue that measurement, analysis and modelling of urban growth are required to better forecast, and ultimately manage, current and future urban development (Herold et al., 2003). In this respect, improvements in understanding the sources, timeline and impacts of the process of urbanisation are essential to introducing approaches to better management and planning of urban development (Klostermann, 1999; Longley \& Mesev, 2000; Herold et al., 2003). In this study, we explore the case of China's urbanisation and urban growth as a leading example in the developing world. The case of China demonstrates current challenges and approaches to urban-scale energy management scenarios. In their concluding remarks, Peng et al. (2018) highlight the changes in economic growth patterns in China and argue about the effects on China's energy demand from the presentation of five potential scenarios: 1) the business-as-usual (BAU) scenario that suggests the baseline of growing energy demand and economic growth, 2) a more economic-oriented approach that suggests acceleration of the economic transition, 3) A unrealistic scenario of capping coal consumption before the start of the $14^{\text {th }}$ FYP (i.e. 2020), 4) a scenarios which is based on unconventional gas 
production, and 5) a combination of scenarios apart from the BAU. The implications from these scenarios are on goals of peaking carbon emissions which is also closely correlated with energy use policy and energy targets by 2030 . While we believe capping the coal consumption at an earlier phase may not be so realistic, it is anticipated that economic growth could alter structurally through a greener transition. As it already happens through green economy transition, we anticipate to see a progress on balancing energy and economic growth, through which energy demand has to be monitored cautiously and alternative modes of energy production and consumption have to take a stronger position.

Issues of demand and consumption continue to be major challenges in transitional phases that China is experiencing now. The said demographic changes, from the perspective of energy demand increase, put a major pressure on medium to larger cities as the urban energy demand are expected to be much higher than the other cities or communities. The balance to gradually reduce the BAUs would take a longer time that may see structural changes or institutional rearrangements that could help to develop new strategies for energy demand reduction or alternative energy use. The combination effect of improving the energy consumption structure (Kuznets, 1965; You, 2013) and reduction of GHG emissions (Peng et al., 2018) would set changes to different energy use, even though the demand may continue to grow. The emphasis, as highlighted by Golley et al. (2013) is then likely to be at the regional level, which could reflect on the demand-side perspective (Sheng et al., 2014) and create an ecosystem between urban and rural areas (Cheshmehzangi, 2016). In this regard, we can foresee no reduction in demand and consumption, but only potential changes in energy management at the regional and city levels, as well as changes in energy structure and economic growth patterns. These come at the time when China is at the crossroads, being main fossil fuel based for energy consumption and in a transformative stage of energy restructuring towards non-fossil energy (Zhang et al., 2020). This is also similar to global energy consumption patterns that are much higher for energy use from three main resources of crude oil, coal, and gas (i.e. three highest resources respectively) (Markandya \& Wilkinson, 2007; Ritchie \& Roser, 2015; BP Statistical Review of World Energy, 2019). Hence, we anticipate the timeline of the next 10 years to be very effective in making substantial changes to key aspects of energy use and demand, some of which would lead to significant changes on urban energy management. If to be considered as a prolonged transition period, then a low carbon transition is just feasible through structural adjustments for energy demand (ibid) with potential reduction in carbon intensity (He, 2014), development of new benchmarks (Ma et al., 2020), and a chance to boost the national strategy on energy production and consumption revolution (NDRC, 2016). In doing so, the transition will oppose the current trends of BAUs and lead towards a green economy direction.

The following section focuses on the case of China more precisely by first explaining more about China's urbanization and then delving into China's energy 
demand, reviews of the last two five-year-plans (FYPs), and the main considerations of 2020-2030 on energy issues and energy management.

\section{China's Urbanisation and Urban Growth}

Urbanization in the global context has already passed $50 \%$ of the total global population and is expected to reach $60 \%$ by 2030 . The highest growth rate is currently in medium-sized cities where there is significant rural-to-urban migration taking place. As driving forces in economic growth, cities are growing into major economic hubs and are forecast to grow in number in developing countries, especially those that are now experiencing rapid growth specifically associated with their GDP or economic growth. Undoubtedly, one of the greatest examples of urban growth for the past few decades is China, which is predicted to develop into a global model for other Asian, African, and Latin American countries. China, holding one-quarter of the world's largest urban areas, remains one of the most rapidly developing countries, experiencing significant rural-to-urban migration. For decades, China has concentrated on urban growth and has increased the income and opportunities to fulfill the demands of the population. In the 1980 s, China experienced unprecedented growth with an urbanization rate of 19.6\%; and since then the Chinese government has been examining solutions to tackle the growing energy consumption of its cities (World Bank, 1997). It was estimated in McKinsey \& Co's Report (2009) that by 2030, more than $60 \%$ of China's total population will live in urban areas. Nevertheless, China reached this figure 10 years earlier in 2020. Some sources estimate the rate to be $70 \%$ $75 \%$ by 2025 (Figure 2) (also see McKinsey \& Co's Report, 2009), which is very likely based on the current urbanization patterns across the country. With the focus on coastal areas during the 1980s and shifting attention to inland areas in the 1990s, China has developed many cities that are now major energy consumers in the country. Managing those cities or high-consumer hubs are of major concern to many economists, planners, and city specialists.

According to McKinsey \& Co's Report (2009) on China's urbanization, 40 billion square meters of floor space is required over the next two decades to provide the built environment for the new urban residents of China. This is based on the increasing urban population as projected and shown in Figure 2. The promotion of constructing new buildings due to rapid urbanization ( $\mathrm{Hu}$ et al., 2017; Zhang et al., 2020) has increased the number of construction sites across the country, with five times construction in 2016 as compared to 2000 (NBS, 2017). Moreover, having become the world's largest construction market in 2010 (The Global Construction 2020 Report, 2011), China was expected to constitute one-fifth of the global construction industry by 2020. As per records (ibid), China had the fifth fastest-growing markets in 2009 and was expected to be the third in 2020. Nonetheless, the estimated figures of GDP-PPP ranking of countries suggest China was ranked the first in 2017, some of it is due to the rapid development that has occurred in smaller to medium scale cities since 2014 and 


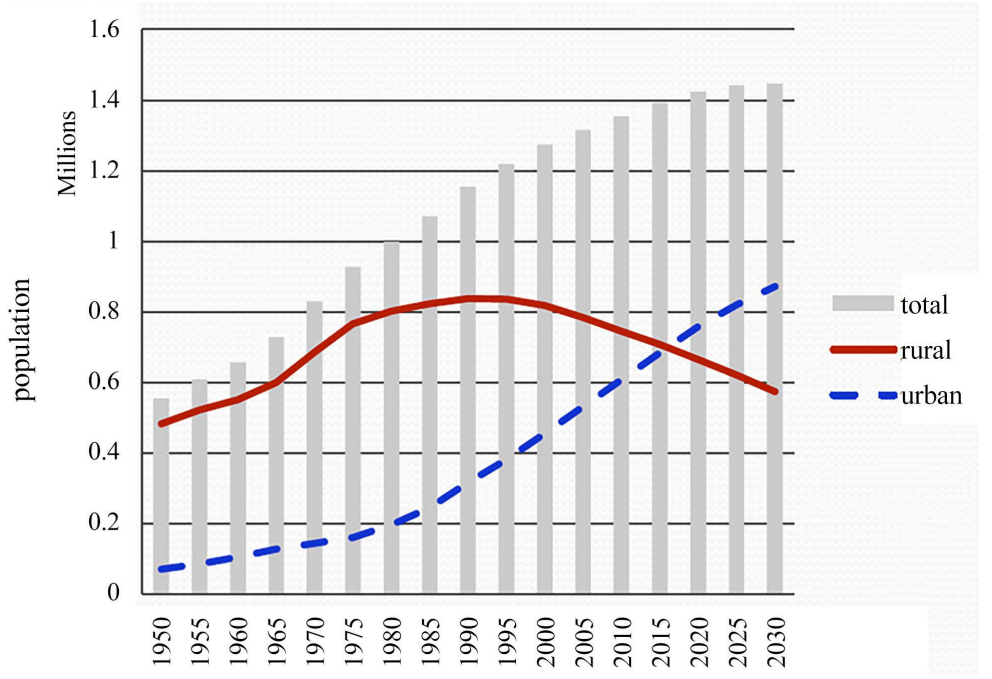

Figure 2. Changes in Chinese rural population from 1950 to 2030 with five-year intervals in line with five-year plans (FYPs) in China, indicating an estimated 70\% - 75\% urban population by 2025. (Source: Adapted from United Nations Data and Projections; United Nations, 2005).

as part of the NUP (Cheshmehzangi, 2016). As noted earlier, the more recent growth has occurred mostly due to rural to urban migration, enabling the country to become more urbanized and alleviating poverty. These were also in line with the plans of the 12th and 13th FYPs. Nevertheless, demand and consumption are already rising drastically, requiring management scenarios to overcome any downturn in urban growth. The energy-related demand puts a major pressure on key factors of climate change mitigation plan, achieving the sustainable development goals (SDGs), capping the coal consumption, reaching the peak by 2030, etc. Also, we can see the correlation between urbanization growth and demand increase, especially in the energy sector, which indicates an important area of research in urban management studies. There are examples of what has been done in the last one decade, specifically through the 12th and 13th FYPs, and there are key factors that could be included from the earlier lessons to signify what we could be done next by 2030 (i.e. in the timeline of the 14th and 15th FYPs). While in recent years there has been more fluctuation in the construction sector, the urban development patterns are continuing rapidly. The change is mainly seen in larger cities where urban development has reached or is reaching its peak. Thus, we can see growth in most parts of the country some that are emerged in recent years since 2014.

Although China's overall growth has been mostly concentrated in the east and south coastal areas for the past few decades, its urban growth is now taking place evenly between the coastal and inland regions. This has been raised as one of the mainstreams of urbanization and urban development in the NUP (Cheshmehzangi, 2016). Such urban growth is developing many major cities, new development zones, and new urban clusters. The current patterns are also developing new cities as well as expanding smaller urban areas into larger cities. There- 
fore, there are significant pressures on energy demand, consumption, and population growth; often bringing about other related urban problems (economic, environmental, and social) in the long run. The significant pressure on urban energy demand is an example that requires careful attention from the urban energy management perspective. As a result, China currently invests in many new developments, examining possibilities to reduce future pressures and minimize the unforeseen problems related to growth in energy demand and population. Such experimental cases are yet to scale up and be implemented at a larger scale. Here, we reflect on some of these examples and cross-check any trends of research and practical work that are emerging in this important field and from the perspective of urban management.

\section{Case Study: Urban Energy Demands in China}

At first, we look at China's urban demands on energy, in particular, to elaborate more on the recent and current situation before we could suggest for urban energy management directions. This study aims to provide an overview of what is on the ground now and reflect on the realities of urbanization challenges faced in countries like China. As mentioned earlier, China is the main example due to its important position in the developing world, and hence by studying its recent transitions and current pathways, we could shed light on some of the generalities that could help to better decide on the next steps of urban energy management. As Nobuo Tanaka, Executive Director of the International Energy Agency (IEA) (n.d.) puts it well: "One point is certain. The centre of gravity of global energy demand growth now lies in the developing world, especially in China and India. But uncertainties abound'. Hence, it is important to evaluate and foresee the main issues of energy demand growth that may need to be considered more cautiously as part of the urban management planning in the next decade or so.

As the structure of China's economy indicates, the growth rate is greater in the areas of industry and services (Figure 3), meaning that urbanization remains as a major mechanism for China's development and growth. Consequently, this indicates there will be an upsurge in urban demand and energy consumption as part of the process of urbanization and growth. Moreover, the overall composition of energy demand remains one of the major urbanization challenges for China. Changes in lifestyle and developing technologies have already become a major means of optimizing energy efficiency in urban regions. Yet, these approaches are either happening at a rapid pace or are not taking place according to overall population needs; hence, there are still major concerns about the implications of urbanization and how these may be tackled.

For China, the growing demand for energy is largely due to the rise in income, overall national growth, and constant migration of rural population to urban regions. As discussed by Overman \& Venables (2005), urbanization and income rates are strongly interrelated, and urban opportunities are considered essential drivers of economic growth. As a result, China's urban structure is developing 


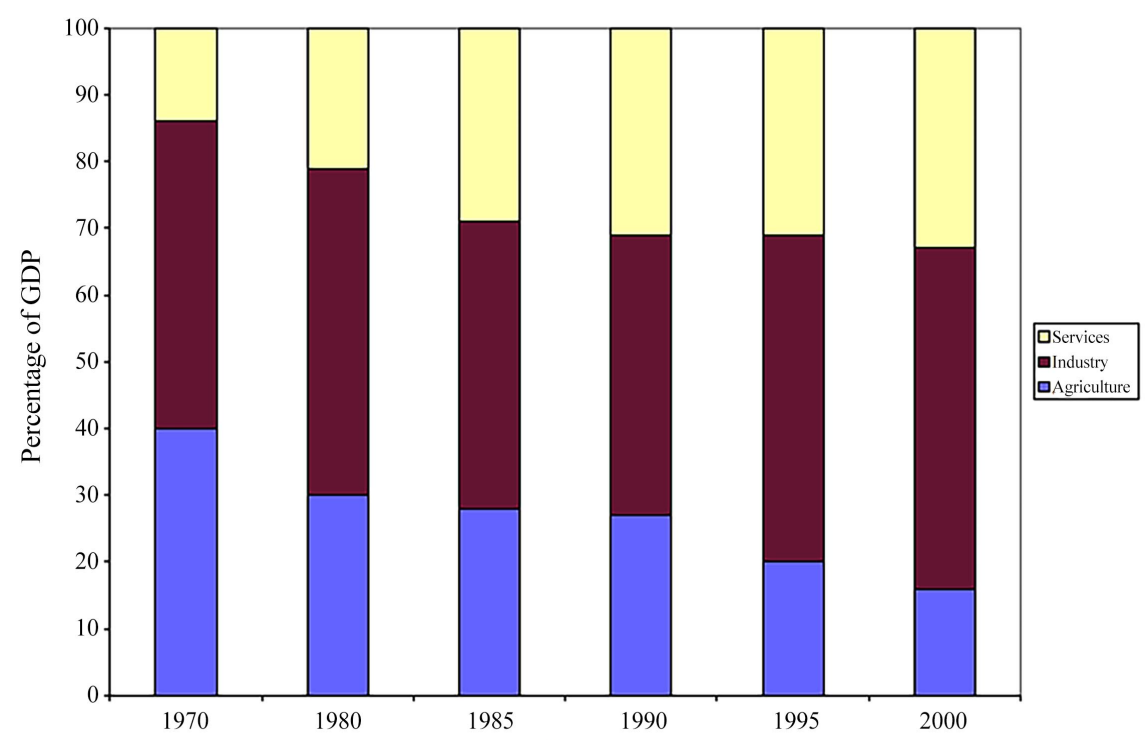

Figure 3. Structure of China's Economy from 1970 to 2000, indicating gradual changes in the reduction of the agriculture-based economy and the gradual increase in industry-based economy, while the service-based economy has been relatively steady with a gradual increase from the mid-1980s onwards but with an earlier rapid increase in the 1970s and 1980s (Source: adapted from China Statistical Yearbook)

rapidly and has begun to take shape beyond urban regions, connecting rural with the urban. Yet, there remains considerable pressure between supply and population demands, which is also changing the pattern of growth in some parts of the country. The trend of urban growth in China, similar to other developed and developing countries has its own implications and challenges. However, what makes China an interesting example is the size of its population (specifically in comparison to the developed world) and current experimental approaches that are making China a leading model in the developing context.

\subsection{An Overview of the Last Two Five-Year Plans $\left(12^{\text {th }}\right.$ and $13^{\text {th }}$ FYPs)}

The reason to select the recent two five-year plans (FYPs), i.e. 12th and 13th FYPs, is that we see a tangible development on the energy and environment factors (Lewis, 2011; Seligsohn \& Hsu, 2011) since the emergence of ecological civilization in 2007 (Deng \& Cheshmehzangi, 2018), and further establishment of the sustainability initiatives in 2009 and onwards. This is also phrased as the era of China's green revolution (China Dialogue, n.d.), which was the inception of new pathways that differ from the previous FYPs. The later updates on the topic suggested the same ideas (McKinsey \& Company, 2009) and the more enhanced version of 'Red China's Green Revolution' (Eisenman, 2018). Similar thinking is also mentioned by Liu et al. (2018), who suggest China's energy revolution strategy that continues to 2030. However, we could see traces of progress from 11th FYP that were then developed into the following ones from 2010 onwards (Li et al., 2019). Yet, the earlier evaluations of the 11th FYP (ibid, p. 5) indicate 
that achieving the targets was not possible due to high energy density and pollution targets, which were mainly caused by a "continuing stress on growth and a lack of effective enforcement". This has then been developed into the next phase of rebalancing the national economy, which brought in the two main pillars of energy and environment. The needs to do so are actually highlighted in the 10th FYP, but with the growing difficulties of the 10th and 11th FYPs, the achievements were not significant.

We can argue that the release of the plan for energy development as part of the 12th FYP was a major move that signified the starting point of further energy planning and management pathways. The move was developed based on four key achievements of the 11th FYP, which provided a solid foundation to promote the energy development plans of the following FYPs. As highlighted by China Briefing (2013, online source), these achievements included: 1) National output of primary energy reaching 2.97 billion tons of standard coal in 2010, ranking first in the world for the fifth consecutive year, 2) The scale of installed electricity generation capacity reached 970 million kilowatts in 2010, ranking first in the world, 3) Nuclear power under construction reached 20.9 million kilowatts in 2010, taking up more than 40 percent of nuclear power under construction worldwide, and 4) Energy consumption per unit of GDP decreased by 19.1 percent (ibid). By reflecting on these, four primary energy aspects and six characteristics were developed in the 12th FYP (US-China Cleantech, 2012). As shown in Figure 4, this new strategic plan then developed into a more substantial development on energy aspects that then led to the later urban development and urbanization strategies of 2014-20 (Cheshmehzangi, 2016).

From China's 12th FYP, it is evident that both science and technology play major roles in the ongoing trends of China's growth and development. These applied to the main energy targets of $16 \%$ reduction in energy density, $17 \%$ reduction in carbon density, and $11.4 \%$ increase of non-fossil fuel energy sources for primary energy consumption. Similar targets then continued and applied to the 13th FYP. Also by 2030, China is expected to priorities the development of energy systems and solutions to fulfill the growing demand. The scientific development approach alongside the technological shift for energy systems, efficiency, and optimization are very likely to remain major components of China's strategies for energy management.

Merged with the "environment" pillar, and as previously expected from the progress of the 12th FYP, the energy aspect took a main position in the 13th FYP. This meant a plan to emphasize further on cleaner and greener economy, which was aimed to develop a stronger commitment to environmental management and protection. These then led to the development of the 2020 targets, which included both national and energy plans (Ma, 2016). In line with this proposition, the development of the Sustainable Energy Action Plan (SEAP) is considered to be in line with the NUP's timeline of 2014-2020. The 2020 energy targets are shown in Table 2 below. 


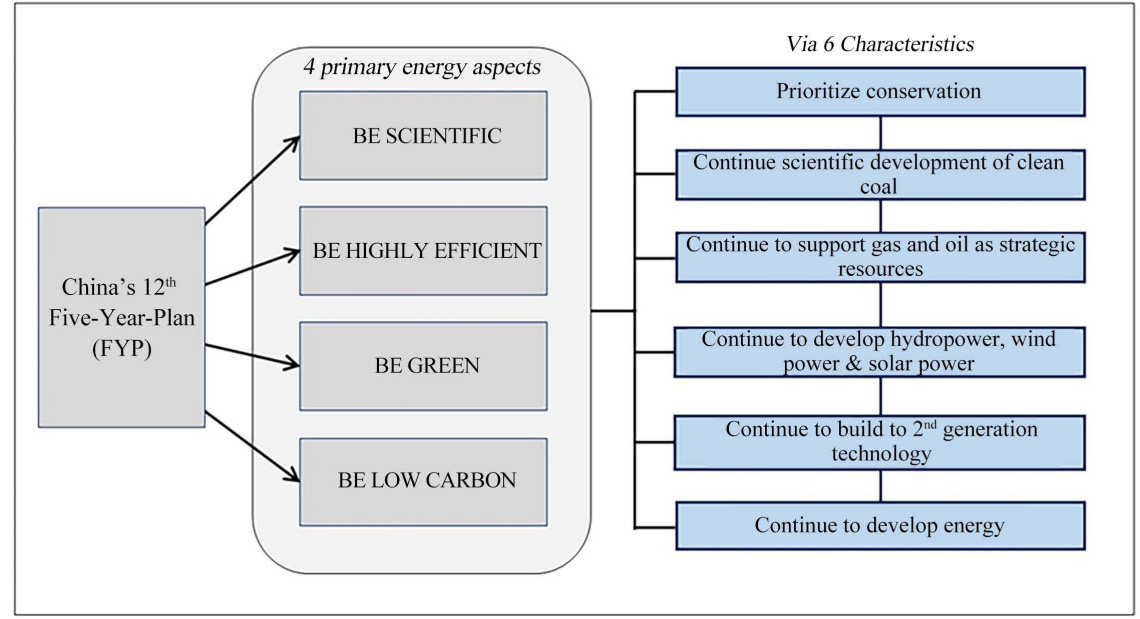

Figure 4. The 12th Five Year Plan-Energy Characteristics and Aspects (Source: adapted and redrawn from US-China Cleantech website; originally based on Chai Songuye's four characteristics, October 2012).

Table 2. 2020 energy targets as well as installed capacity targets in line with SEAP 2020, National 13th FYP, and Energy 13th FYP, and in comparison with 2015 actual levels prior to the 13th FYP timeline (Source: adapted and redrawn from Ma, 2016).

\begin{tabular}{|c|c|c|c|c|}
\hline 2020 Targets & $\begin{array}{l}\text { SEAP } \\
(2014-2020)\end{array}$ & $\begin{array}{l}\text { National } \\
13 \text { FYP }\end{array}$ & $\begin{array}{l}\text { Energy } \\
13 \text { FYP }\end{array}$ & $\begin{array}{l}2015 \text { actual } \\
\text { levels }\end{array}$ \\
\hline Energy consumption cap & About 4.8 Gtce & 5 GTce & $\begin{array}{l}\text { No more than } \\
5 \text { Gtce }\end{array}$ & 4.3 Gtce \\
\hline Coal consumption cap & $4.2 \mathrm{Gt}$ & N/A & Less than $4.1 \mathrm{Gt}$ & $3.96 \mathrm{Gt}$ \\
\hline Energy Consumption/GDP & N/A & $\begin{array}{l}-15 \% \text { from } \\
2015 \text { level }\end{array}$ & N/A & $\begin{array}{l}-18.2 \% \text { from } \\
2010 \text { level }\end{array}$ \\
\hline $\mathrm{CO}_{2}$ Emissions/GDP & N/A & $\begin{array}{l}-18 \% \text { from } \\
2015 \text { level }\end{array}$ & N/A & $\begin{array}{l}-20 \% \text { from } \\
2010 \text { level }\end{array}$ \\
\hline $\begin{array}{l}\text { Coal in primary energy } \\
\text { consumption }\end{array}$ & $62 \%$ & N/A & $58 \%$ & $64 \%$ \\
\hline $\begin{array}{l}\text { Non-fossil fuel in primary } \\
\text { energy consumption }\end{array}$ & $15 \%$ & $15 \%$ & More than $15 \%$ & $12 \%$ \\
\hline \multicolumn{5}{|l|}{$\begin{array}{l}2020 \text { Targets } \\
\text { (installed Capacity) }\end{array}$} \\
\hline Wind & $200 \mathrm{GW}$ & N/A & $210-250 \mathrm{GW}$ & $129 \mathrm{GW}$ \\
\hline Solar & $100 \mathrm{GW}$ & N/A & $110-150 \mathrm{GW}$ & $43 \mathrm{GW}$ \\
\hline Hydro & $350 \mathrm{GW}$ & N/A & $340 \mathrm{GW}$ & $320 \mathrm{GW}$ \\
\hline Nuclear & $58 \mathrm{GW}$ & $\mathrm{N} / \mathrm{A}$ & $58 \mathrm{GW}$ & $26 \mathrm{GW}$ \\
\hline
\end{tabular}

As it is seen from the differences between 2015 levels and proposed levels of 2020, the extended energy targets of the 13th FYP puts a major pressure on how the structural changes could lead to the further establishment of energy-related progression, particularly in terms of efficiency enhancement, capping, and consumption reductions. Moreover, China's installed capacity for non-fossil energy 
sources became the largest globally in 2017 and also reached some of the 2020 energy targets earlier. In line with the challenges of growing energy demand, higher aims were put in place for the renewable energy sector. These include a further emphasis on standards (Fan et al., 2019), benefits and costs (Li \& Patiño-Echeverri, 2017), policy impacts (Chen \& Chen, 2019), adjusting energy consumption structure (Xu et al., 2020), the roles of economic factors (Wang \& Feng, 2018), etc. The push on this sector was to increase the initial capacity that was proposed in 2014 as the energy demand has been continuously increasing. The gradual decrease in primary coal consumption also does not match the growing capacity of the renewable energy sector, meaning that the overall energy demand especially for the urbanizing areas is still increasing. The continuous build-up of coal-fired power capabilities also indicates the challenges of reaching a low carbon economy in the short term.

In summary, we can see less emphasis on cities and urban management issues during the 12th FYP, while the role of cities become more visible in the 13th FYP. This is partly due to four primary facts including continuing urbanization (and associated with the NUP), highly ambitious 2020 target plans, climate agreements from Paris talks in 2015, and initiatives to achieve the SDGs. The so-called green revolution is, therefore, not simply limited to energy structuring and increasing the renewable energy sector capacity, but is also tangled with how urbanization plans will evolve in this transitional phase. The impacts on urban development modes and how cities will turn out to be key drivers and challenges of the energy sector are the main focus of the 2020-2030 era. In the lifespan of 14th and 15th FYPs, we see the importance of urban management even more than the previous decade. In the following sub-section, we ask the main question of what do energy targets mean for cities and urban management. By responding to this crucial question, we delve into further discussions that suggest pathways towards urban energy management, and specifically from the dimension of urban energy demand.

\subsection{Main Considerations for the Next Two Five-Year-Plans by 2030: What Do "Energy Targets" Mean for Cities and Urban Management?}

Economic development, energy demand, and carbon emission remain the three main challenges of 2020-30 ( $\mathrm{Li}$ et al., 2019). The growing urbanization to the $+70 \%$ rate by 2030 will pose a major challenge to respond to the energy demands of the country. The increasing energy demands already put pressure on the set 2020 targets, and for cities, these will mean different approaches towards more investment in the renewable energy sector, development of regional-level initiatives, and strengthening the urban-rural relations in a holistic network of energy production and consumption. Some of these pathways could lead to multi-scalar initiatives, such as enhancement of renewable portfolio standards (Fan et al., 2019), improvement of energy efficiency and peak carbon emissions (Guo et al., 2017; Li et al., 2019), local decomposition of carbon intensity targets (Zhou et al., 
2013; Chai et al., 2015; Wang et al., 2018), etc. But there are also regional differences (Li et al., 2009; Ying et al., 2016; Sheng et al., 2018) that are continuously making a major gap between different parts of the country, creating an imbalance in energy intensity and use. Some of these will need to addressed through $\mathrm{CO}_{2}$ control policies ( $\mathrm{Pu} \&$ Hayashiama, 2012), more efficient utilization of energy resources, such as renewable energies (Fan et al., 2019), and a better understanding of the energy structure effect (Wang \& Feng, 2018) in a longer-term. For cites, these are likely to be even more challenging as the recent convergence analysis of city-level energy intensity indicates more policy support (Zhu \& Lin, 2020).

By responding to the issues associated with the city-level energy management issues, the more recent debates argue about inequalities of city-level energy efficiency (Zhang \& Zhou, 2020), which are affected by technological innovation (Wang \& Wang, 2020). There are also essential needs for city-level transition strategies, through which development modes could be discussed more holistically (Xie et al., 2020), the role of renewable energy could be better defined (Yuan et al., 2018), dynamics of energy intensity could be distributed more strategically (Wu et al., 2018), and green development could then be promoted in various ways (Deng et al., 2020b). At the city level, these could be seen from the spatial characteristics, similar to the study of Chen et al. (2018) that analyses China's energy productivity (EP) change determinants and from the evaluation of spatial character and distributional evolution in Chinese cities. In their concluding remarks, Chen et al. (2018) refer to the important role of technological and technical efficiency that is also crucial to urban management scenarios when meeting the forthcoming energy targets and carbon emission peak of 2030 or earlier (Su \& Lee, 2020). To achieve this, 2020-30 is likely to be the most crucial time for urban energy management in China.

\section{Discussions: Towards Urban Energy Management}

As argued by the UN Habitat (2006) "Urbanization and economic growth typically happen in tandem; however, equitable distribution of benefits and opportunities remains a challenge". The main challenge in rapidly developing countries (like China) is not just energy or development but the management of both through optimization, design, and delivery (Hall \& Pfeiffer, 2000). The same that we see that happened in the last two decades and we expect to see happening in this decade, too. Hence, we argue the focus needs to be towards achieving energy efficiency for the energy consumers of the built environment. This will require introducing and implementing efficient and effective solutions. This will ultimately ensure a reduction in the level of energy use in the built environment and will help to enhance fundamental urban programs focusing on delivering effective interventions towards urban growth.

To face these energy challenges, there is a requirement to predict and model urban growth. In the long term, this will then help to optimize urban manage- 
ment as well as city-level and regional-level initiatives. This approach will then effect the better management of growth patterns and energy demands, two factors that are still very critical in China. The growing focus on energy and its environmental and economic implications has become a global matter, as to better develop management systems, maximize energy efficiency, and minimize carbon emissions. One important experimental approach in the context of China is to develop new benchmarks, as we have seen commonly happened in experimental cases across the country. With an aim towards energy management of urban areas, in particular, creating a set of benchmarks (i.e. to develop possible solutions or methods for energy efficiency) seems a sensible consideration in the current and forthcoming phases of growth in China. It is also claimed (US-China Cleantech, 2012) that in the period of the 11th FYP, China managed to reach its target of decreasing energy intensity (for energy use) by $20 \%$. The later achievements of 12th FYP and 13th FYP then suggested for more rigorous reinforcement of energy policies, and the development of new and more enhanced standards. These recent progressions are expected to develop further in the next two FYPs till 2030. As a result, China currently has the largest number of eco-development, green development, smart city initiatives, low carbon projects, green building initiatives, and sustainable projects that are so far recognized as a series of experimental projects and could now offer a platform for energy systems and urban energy management advancements.

As the increasing urbanization indicates, reduction in energy demand is not necessarily possible, but the reduction in energy consumption can be very significant at an urban scale. This, of course, requires holistic urban energy management as advocated throughout the paper. A systematic approach appears to be one of the main approaches to urban energy management. For instance, the approach to modeling and analysis of urban energy systems is already developing on a global scale. One successful example is the joint program between BP and Imperial College London (2006-12) (Report from 2011), which explores ways of saving energy and reducing consumption at the city scale. This requires a multi-layered approach to analyzing and understanding service networks, resource flow, agent activities, and land use. All these four areas come under the overarching area of urban management. In doing so, we are able to have a better city layout optimization model, a more integrated land use analysis that suggests transport demand model, a holistic service network model, ad a better integration of energy infrastructure and resource technologies in the urban energy systems (ibid). Although they may differ in operation in different contexts, urban energy systems can be modeled thoroughly to identify possible ways of energy reduction and energy efficiency enhancement. Other similar international projects such as Energy Sector Management Assistance Programme (ESMAP, 2011), Global Secure (2018), Low Carbon and Climate Resilient Urban Development Project (ADB, 2018), and many more examples, explore the possibilities of having systematic and integrated approaches to planning, operating and the design 
of urban energy systems. Through these, we can see an opportunity towards a more sustainable urban energy management.

The current two challenges of environmental degradation and energy scarcity (Jiang et al., 2018; Lin \& Zhou, 2019; Shao et al., 2019; Zhu \& Lin, 2020) are likely to continue as bottlenecks of sustainable development in China. Nevertheless, the move towards energy structure changes (Wang et al., 2016; Yang et al., 2018; Wang et al., 2020), new policy formation for cities of different sizes (Deng et al., 2020c), progress in green economy improvement (Li \& Lin, 2016; Pan et al., 2019), efficiency change in technological progress (Pan et al., 2019; Zhu et al., 2019; Zhou et al., 2020), and clean energy to gradually enter the social market (Deng et al., 2020a), are just inevitable. Under the overarching area of urban management, we see urban energy management would become every important in facing the forthcoming challenges and developing new initiatives towards sustainable growth.

\section{Limitations, Contributions, and Future Research}

This study's main limitation is the availability of data that are mostly associated with recent transitions and the development of the forthcoming FYPs, which are likely to be covered in future research in the field or associated with areas of urban sustainability, urban management, and sustainable development. The correlation between the urban economy and the increase of energy demand is already studied, which demonstrates a major challenge in the coming years particularly for developing countries like China. The rapid growth and urban development, as studied in this research paper, could provide a better understanding of why urban energy management is essential. This study also offers a better overview of recent transitions for urban energy demand, and the importance of managing this transition towards a sustainable pathway or multiple pathways that could achieve sustainable development down the line, but not too far ahead. This study also highlights some of the key national-level challenges by exploring the recent FYPs, and suggests there are serious threats in achieving sustainability and managing the growth of cities in the coming decade or so. The role of SDGs is important through this process (Cheshmehzangi \& Dawodu, 2019) and suggests a major opportunity for exploring new approaches to urban development and tackling its current and envisaged energy challenges.

This study contributes to existing research studies by providing findings that highlight a brief review of China's recent FYPs in light of recent and future development on aspects associated with urban energy targets and urban energy management. The next 10 years, given that it lasts for the remaining timeline of the SDGs, will be crucial for China's sustainable development. Whether there will be innovation and digital technologies, or optimization through new approaches of development, the expected methods are likely to be through integrated planning and development methods. Hence, future research could adopt integrated solutions (Cheshmehzangi et al., 2017) specifically to optimize the 
performances on urban energy management and environmental aspects. As a result, future studies in the field are likely to be associated with longer-term transition studies. These should include a larger network of energy parameters and provide more comprehensive energy management solutions. While this study focuses on the recent two FYPs, the longer-term transitions could be looked at from the earlier dates and to include a larger set of data on urban energy data and details of the FYPs from at least the 1970s onwards. These data could be looked at comparatively with other locales to better evaluate the institutional frameworks and provide action plans and policy development that is in line with not only the SDGs but the longer-term sustainable development for the energy sector, specifically for the urban energy sector. The following section concludes this study and highlights the main findings offered in this paper.

\section{Conclusion}

One of the main challenges of urban growth in the context of developing countries is the vital requirement for emerging a unique model specifically befitting developing countries that are either in the process of industrialization or having a rapid urbanization rate. Although China is portraying itself as a model for urban growth and urbanization, it is still progressing towards better management of its energy demands and consumption. Despite the challenges, China is seeking alternative methods and potential solutions to reduce the energy demands of its rapidly growing urban population. Developing countries are looking to replicate China's successes in boosting urbanization and economic growth, which has made China a key economic player in the international arena. Both scientifically and technologically, systematic approaches to modeling, measuring, and managing the energy demands and consumption are developing rapidly. At the city level, these should be dealt with through holistic urban management.

In this study, we have briefly reviewed China's recent energy transitions of the last two decades in order to better portray the existing challenges that are yet to be faced before the 2030 targets. By assessing the progress of China's recent three five year plans, we have highlighted the continuing challenges that are tangled with urbanization and economic growth. The two cannot be neglected in the field of energy management, particularly that we are dealing with continuously increasing energy demand and consumption. The role of cities and urban management, as highlighted in this study, is evident in how China should manage its next phase of development. The emphasis on urban management, specifically from the urban energy management perspective, is regarded as a prolonged challenge that requires immediate attention. Suggestions that are already discussed in the previous section provide pathways towards sustainable urban energy management that could lead to better control of carbon emissions, too.

Finally, it can be argued that beyond demographic and land-use changes, urbanization remains key for sustainable development and can promote economic reforms that can significantly reduce poverty in the longer-term. However, the 
surge of rural to urban migration has led to calls for huge investment in construction, transportation, and infrastructure planning, which are identified as major energy consumers of the built environment. The unsustainable patterns of production and energy consumption require further optimization and assimilation to comprehend the significance of energy-efficient urban growth that has not yet been established. These matters are certainly very important for policy and decision making that require reductions for energy consumption and demand. Yet, policy-makers have been overly concerned with policy strengths but achieved too little in shaping manageable urban growth. Finally, it is important to note that improvements in design information and decision making require more than a predictive model but rather a prescriptive approach.

\section{Acknowledgements}

The author would like to thanks the National Natural Science Foundation of China (NSFC) for the provision of funding for project number 71950410760.

\section{Conflicts of Interest}

The author declares no conflicts of interest regarding the publication of this paper.

\section{References}

Acs, Z. (2002). Innovation and the Growth of Cities. Cheltenham: Edward Elgar. https://doi.org/10.4337/9781843766933

Adams, D. C. (1994). Urban Planning and the Development Process. Oxon: Routledge.

ADB (Asian Development Bank) (2018). Jilin Yanji Low-Carbon Climate-Resilient Urban Development Project: Initial Poverty and Social Analysis. https://www.adb.org/projects/documents/prc-50322-002-ipsa

Agenda 21 (2012). Sustainability Plan-Guidance on Development, the United Nations.

Akalpler, E., \& Shingil, M. E. (2017). Statistical Reasoning the Link between Energy Demand, $\mathrm{CO}_{2}$ Emissions and Growth: Evidence from China. Procedia Computer Science, 120, 182-188. https://doi.org/10.1016/j.procs.2017.11.227

BP and Imperial College London (2011). The Fifth Annual Report for the Urban Energy Systems Project.

BP Statistical Review of World Energy (2019). Global-By Country and Region, Annual Data Since 1952. https://www.BP.com

Chai, Q. M., Chen, Y., \& Xu, H. Q. (2015). Study on the Decomposition Scheme of Regional Indicators under the Dual Control Targets of Carbon Intensity and Total Quantity: A Case Study of Wenzhou City. Energy China, 37, 28-32. (In Chinese)

Chen, H., \& Chen, W. (2019). Potential Impacts of Coal Substitution Policy on Regional Air Pollutants and Carbon Emission Reductions for China's Building Sector during the 13th Five-Year Plan Period. Energy Policy, 131, 281-294.

https://doi.org/10.1016/j.enpol.2019.04.047

Chen, J., Xu, C., Song, M., \& Liu, X. (2018). Driving Factors of China's Energy Productivity and Its Spatial Character: Evidence from 248 Cities. Ecological Indicators, 90, 18-27. https://doi.org/10.1016/j.ecolind.2018.02.056 
Chen, X., Shuai, C., Wu, Y., \& Zhang, Y. (2020). Analysis on the Carbon Emission Peaks of China's Industrial, Building, Transport, and Agricultural Sectors. Science of the Total Environment, 709, Article ID: 135768.

https://doi.org/10.1016/j.scitotenv.2019.135768

Cheshmehzangi, A. (2016). China's New-Type Urbanisation Plan (NUP) and the Foreseeing Challenges for Decarbonization of Cities: A Review. Energy Procedia, 104, 146-152. https://doi.org/10.1016/j.egypro.2016.12.026

Cheshmehzangi, A., \& Dawodu, A. (2019). Sustainable Urban Development in the Age of Climate Change-People: The Cure or Curse. Germany and Singapore: Palgrave Macmillan. https://doi.org/10.1007/978-981-13-1388-2

Cheshmehzangi, A., Zhu, Y., \& Li, B. (2017). Application of Environmental Performance Analysis for Urban Design with Computational Fluid Dynamics (CFD) and EcoTect Tools: The Case of Cao Fei Dian Eco-City, China. International Journal of Sustainable Built Environment, 6, 102-112. https://doi.org/10.1016/j.ijsbe.2017.01.004

China Briefing (2013). China Reeases 12th Five-Year-Plan for Energy Development. https://www.china-briefing.com/news/china-releases-12th-five-year-plan-for-energy-d evelopment/

China Dialogue (n.d.). China's Green Revolution: Energy, Environment, and the 12th Five-Year-Plan. https://chinadialogue.net/en/uncategorized/4255-China-s-green-revolution/

Deng, L., Bi, C., Jia, J., Zeng, Y., \& Chen, Z. (2020a). Effects of Heating Activities in Winter on Characteristics of $\mathrm{PM}_{2.5}$-Bound $\mathrm{Pb}, \mathrm{Cd}$ and Lead Isotopes in Cities of China. Journal of Cleaner Production, 265, Article ID: 121826. https://doi.org/10.1016/j.jclepro.2020.121826

Deng, W., \& Cheshmehzangi, A. (2018). Eco-Development in China: Cities, Communities and Buildings. Germany and Singapore: Palgrave Macmillan. https://doi.org/10.1007/978-981-10-8345-7

Deng, W., Cheshmehzangi, A., Ma, Y., \& Peng, Z. (2020b). Promoting Sustainability through Governance of Eco-City Indicators: A Multi-Spatial Perspective. International Journal of Low-Carbon Technologies, ctaa038. https://doi.org/10.1093/ijlct/ctaa038

Deng, Z., Qin, M., \& Song, S. (2020c). Re-Strudy on Chinese City Size and Policy Formation. China Economic Review, 60, Article ID: 101390. https://doi.org/10.1016/j.chieco.2019.101390

Devins, D., Lodorfos, G., Kostopoulos, I., \& Webber, D. (2016). Innovation and Growth in the City Region: Microeconomic Evidence of Asymmetries. International Journal of Innovation Management, 20, Article ID: 1650032. https://doi.org/10.1142/S1363919616500328

Duranton, G. (2011). Innovation in Cities: Classical and Random Urban Growth Models. In D. Audrestch, O. Falck, S. Heblich, \& A. Lederer (Eds.), Handbook of Research on Innovation and Entrepreneurship (pp. 137-149). Cheltenham: Edward Elgar.

Eisenman, J. (2018). Red China's Green Revolution: Technological Innovation, Institutional Change, and Economic Development under the Commune. New York: Colombia University Press. https://doi.org/10.7312/eise18666

Elzen, M. D., Fekete, H., Höhne, N. et al. (2016). Greenhouse Gas Emissions from Current and Enhanced Policies of China until 2030: Can Emissions Peak before 2030? Energy Policy, 89, 224-236. https://doi.org/10.1016/j.enpol.2015.11.030

Esmaeeli, M., Kazemi, A., Shayanfar, H. A., \& Haghifam, M. R. (2015). Multistage Distribution Substations Planning Considering Reliability and Growth of Energy Demand. Energy, 84, 357-364. https://doi.org/10.1016/j.energy.2015.03.002 
ESMAP (Energy Sector Management Assistance Programme) (2011). TRACE. Washington DC: The World Bank.

Fan, J.-L., Wang, J.-X., Hu, J.-W., Wangm, Y., \& Zhang, X. (2019). Optimization of China's Provincial Renewable Energy Installation Plan for the 13th Five-Year Plan Based on Renewable Portfolio Standards. Applied Energy, 254, Article ID: 113757. https://doi.org/10.1016/j.apenergy.2019.113757

Fang, K., Tang, Y., Zhang, Q, Song, J., Wen, Q., Sun, H., Ji, C., \& Xu, A. (2019). Will China Peak Its Energy-Related Carbon Emissions by 2030? Lessons from 30 Chinese Provinces. Applied Energy, 255, Article ID: 113852. https://doi.org/10.1016/j.apenergy.2019.113852

Florida, R., Adler, P., \& Mellander, C. (2016). The City as Innovation Machine. Regional Studies, 51, 86-96. https://doi.org/10.1080/00343404.2016.1255324

Global Secure (2018). Sustainable Energy through China-UK Research Engagement. https://www.ncl.ac.uk/guru/research/projects/globalsecuresustainableenergythroughch ina-ukresearchengagement.html

Golley, J., Sheng, Y., \& Zheng Y. (2013). China's Industrialization, "Structural Adjustment and Regional Disparity: Implications for Demand on Metals". In L. Song, \& H. Liu (Eds.), The Chinese Steel Industry's Transformation: Structural Change, Performance and Demand on Resources. London: The Elder Elgar Press.

Gülümser, A. A., Baycan-Levent, T., \& Nijkamp, P. (2010). Measuring Regional Creative Capacity: A Literature Review for Rural-Specific Approaches. European Planning Studies, 18, 545-563. https://doi.org/10.1080/09654311003593614

Guo, W., Liu, X. F., \& Wu, X. L. (2017). Efficiency Allocation of Provincial Carbon Reduction Target in China's Thirteenth Five Year Plan Period. China Population, Resources and Environment, 27, 72-83. (In Chinese)

Hall, P. (1999). Cities in Civilization. London: Phoenix Books.

Hall, P., \& Pfeiffer, U. (2000). Urban Future 21: A Global Agenda for Cities. London: E \& FN Spon.

He, J. (2014). Analysis of $\mathrm{CO}_{2}$ Emissions Peak: China's Objective and Strategy. Chinese Journal of Population Resources and Environment, 12, 189-198. https://doi.org/10.1080/10042857.2014.932266

Herold, M., Goldstein, N. C., \& Clarke, K. C. (2003). The Spatiotemporal Form of Urban Growth: Measurement, Analysis and Modelling. Remote Sensing of Environment, 86, 286-302. https://doi.org/10.1016/S0034-4257(03)00075-0

Hu, S., Yan, D., Guo, S., Cui, Y., \& Dong, B. (2017). A Survey on Energy Consumption and Energy Usage Behavior of Households and Residential Building in Urban China. Energy and Buildings, 148, 366-378. https://doi.org/10.1016/j.enbuild.2017.03.064

Huzayyin, A. S., \& Salem, H. (2013). Analysis of Thirty Years Evolution of Urban Growth, Transport Demand and Supply, Energy Consumption, Greenhouse and Pollutants Emissions in Greater Cairo. Research in Transportation Economics, 40, 104-115. https://doi.org/10.1016/j.retrec.2012.06.035

IPCC (Intergovernmental Panel on Climate Change) (2007). Fourth Assessment Report. Valencia, Spain.

Jiang, L., Folmer, H., Ji, M., \& Zhou, P. (2018). Revisiting Cross-Province Energy Intensity Convergence in China: A Spatial Panel Analysis. Energy Policy, 121, 252-263. https://doi.org/10.1016/j.enpol.2018.06.043

Keong, C. Y. (2005). Energy Demand, Economic Growth, and Energy Efficiency-The Bakun Dam-Induced Sustainable Energy Policy Revisited. Energy Policy, 33, 679-689. https://doi.org/10.1016/j.enpol.2003.09.017 
Klostermann, R. E. (1999). The What If? Collaborative Planning Support System. Environment and Planning B: Planning and Design, 26, 393-408. https://doi.org/10.1068/b260393

Komninos, N. (2011). Intelligent Cities: Towards Interactive and Global Innovation Environments. International Journal of Innovation and Regional Development, 1, 337-355. https://doi.org/10.1504/IJIRD.2009.022726

Krätke, S. (2011). The Creative Capital of Cities: Interactive Knowledge Creation and the Urbanization Economies of Innovation. Chichester: Wiley. https://doi.org/10.1002/9781444342277

Kuznets, S. (1965). Economic Growth and Structure: Selected Essays. London: Heinemann Educational Books Ltd.

Lewis, J. (2011). Energy and Climate Goals of China's 12th Five-Year Plan, Part of Pew Center on Global Climate Change.

https://www.c2es.org/site/assets/uploads/2011/03/energy-climate-goals-chinas-twelfthfive-year-plan.pdf

Li, B., Han, S., Wang, Y., Wang, Y. Li, J., \& Wang, Y. (2020). Feasibility Assessment of the Carbon Emissions Peak in China's Construction Industry: Factor Decomposition and Peak Forecast. Science of the Total Environment, 706, Article ID: 135716. https://doi.org/10.1016/j.scitotenv.2019.135716

Li, J., \& Lin, B. (2016). Green Economy Performance and Green Productivity Growth in China's Cities: Measures and Policy Implication. Sustainability, 8, 947. https://doi.org/10.3390/su8090947

Li, J.-F., Gu, A.-L., Ma, Z.-Y., Zhang, C.-L., \& Sun, Z.-Q. (2019). Economic Development, Energy Demand, and Carbon Emission Prospects of China's Provinces during the 14th Five-Year Plan Period: Application of CMRCGE Model. Advances in Climate Change Research, 10, 165-173. https://doi.org/10.1016/j.accre.2019.09.003

Li, M., \& Patiño-Echeverri, D. (2017). Estimating Benefits and Costs of Policies Proposed in the 13th FYP to Improve Energy Efficiency and Reduce Air Emissions of China's Electric Power Sector. Energy Policy, 111, 222-234.

https://doi.org/10.1016/j.enpol.2017.09.011

Li, N., Shi, M. J., \& Wang, F. (2009). The Effect of Regional Differences and Regional Linkages on China's Regional Policy Effects Is Based on China's Eight-Region CGE Model. Systems Engineering-Theory \& Practice, 29, 35-44. (In Chinese) https://doi.org/10.1016/S1874-8651(10)60075-0

Lin, B., \& Zhou, J. (2019). Impact of Energy Saving and Emission Reduction Policy on Urban Sustainable Development: Empirical Evidence from China. Applied Energy, 239, 12-22. https://doi.org/10.1016/j.apenergy.2019.01.166

Liu, Q., Chen, Y., Teng, F. et al. (2017). Pathway and Policy Analysis to China's Deep Decarbonization. Chinese Journal of Population Resources and Environment, 15, 39-49. (In Chinese) https://doi.org/10.1080/10042857.2017.1286753

Liu, Q., Lei, Q., Xu, H., \& Yuan, J. (2018). China’s Energy Revolution Strategy into 2030. Resoures, Conservation and Recyling, 128, 78-89. https://doi.org/10.1016/j.resconrec.2017.09.028

Longley, P. A., \& Mesev, V. (2000). On the Measurement and Generalization of Urban Form. Environment and Planning A: Economy and Space, 32, 473-488. https://doi.org/10.1068/a3224

Ma, M., Ma, X., Cai, W., \& Cai, W. (2020). Low Carbon Roadmap of Residential Building Sector in China: Historical Mitigation and Prospective Peak. Applied Energy, 273, Article ID: 115247. https://doi.org/10.1016/j.apenergy.2020.115247 
Ma, T. (2016). All Eyes on China's 13th Five-Year Plan for Energy. Leaked Documents Preview China's Plans for Energy Policy over the Next Five Years.

https://dialogochino.net/en/climate-energy/6917-all-eyes-on-chinas-13th-five-year-pla n-for-energy/

Markandya, A., \& Wilkinson, P. (2007). Electricity Generation and Health. The Lancet, 370, 979-990. https://doi.org/10.1016/S0140-6736(07)61253-7

McKinsey \& Co's Report (2009). Preparing for China's Urban Billion.

McKinsey \& Company (2009). China's Green Revolution: Prioritizing Technologies to Achieve Energy and Environmental Sustainability. Ausralia.

NBS (2017). China Statistical Yearbook. Beijing: China Statistics Press.

NDRC (2016). National Strategy on Energy Production and Consumption Revolution (2016-2030). (In Chinese) http://www.ndrc.gov.cn/fzgggz/fzgh/ghwb/gjigh/201705/W020170517397451808076.pdf

Nijkamp, P., Zwetsloot, F., \& van der Wal, S. (2010). Innovation and Growth Potentials of European Regions: A Meta-Multicriteria Analysis. European Planning Studies, 18, 595-611. https://doi.org/10.1080/09654311003593515

Overman, H., \& Venables, A. (2005). Cities in the Developing World. London: International development (DFID). https://ideas.repec.org/p/cep/cepdps/dp0695.html

Pan, W., Pan, W., Hu, C., Tu, H., Zhao, C., Yu, D., Xiong, J., \& Zheng, G. (2019). Assessing the Green Economy in China: An Improved Framework. Journal of Cleaner Production, 209, 680-691. https://doi.org/10.1016/j.jclepro.2018.10.267

Peng, X., Adams, P. D., \& Liu, J. (2018). China's New Growth Pattern and Its Effect on Energy Demand and Greenhouse Gas Emissions. Global Energy Interconnection, 1, 428-442.

Platt, H. (1987). Energy and Urban Growth: A Comparison of Houston and Chicago. South-Western Historical Quarterly, 91, 1-18.

Pu, Y., \& Hayashiyama, Y. (2012). Effects of Carbon Dioxide Control Policy in China by Multi-Regional CGE Model. Frontiers of Economics in China, 7, 580-603.

Qi, Y., Stern, N., He, J.-K., Lu, J.-Q., Liu, T.-L., King, D., \& Wu, T. (2020). The Policy-Driven Peak and Reduction of China's Carbon Emissions. Advances in Climate Change Research, 11, 65-71.

Qi, Y., Wu, T., He, J. et al. (2013). China's Carbon Conundrum. Nature Geoscience, 6, 507-509. https://doi.org/10.1038/ngeo1870

Ritchie, H., \& Roser, M. (2015). Energy. https://ourworldindata.org/energy

S\&P Global Platts (2017). The Evolution of China's Energy Demand. https://www.plattsinsight.com/insight/commodity/cross-commodity/evolution-of-chin as-demand/

Seligsohn, D., \& Hsu, A. (2011). How Does China's 12th Five-Year-Plan Address Energy and the Environment?

https://www.wri.org/blog/2011/03/how-does-china-s-12th-five-year-plan-address-ener gy-and-environment

Shao, S., Chen, Y., Li, K., \& Yang, L. (2019). Market Segmentation and Urban $\mathrm{CO}_{2}$ Emissions in China: Evidence from the Yangtze River Delta Region. Journal of Environmental Management, 248, Article ID: 109324.

https://doi.org/10.1016/j.jenvman.2019.109324

Shearmur, R. (2012). Are Cities the Front of Innovation? A Critical Review of the Literature on Cities and Innovation. Cities, 29, S9-S18.

https://doi.org/10.1016/j.cities.2012.06.008 
Sheng, L. Y., Zheng, X., Zhou, P. et al. (2018). Analysis of the Reasons for the Widening Gap between the North and the South in China. Management World, 9, 16-24. (In Chinese)

Sheng, Y., Shi, X., \& Zhang, D. (2014). Economic Growth, Regional Disparities and Energy Demand in China. Energy Policy, 71, 31-39. https://doi.org/10.1016/j.enpol.2014.04.001

Simmie, J. (Ed.) (2001). Innovative Cities. London: Spon Press.

Su, K., \& Lee, C.-M. (2020). When Will China Achieve Its Carbon Emission Peak? A Scenario Analysis Based on Optimal Control and the STIRPAT Model. Ecological Indicators, 112, Article ID: 106138. https://doi.org/10.1016/j.ecolind.2020.106138

The Global Construction 2020 Report (March 2011). https://www.building.co.uk/download?ac $=1655280$

UN Habitat (2006). State of the World Cities 2006/7. Nairobi.

UN Population Fund (2007). State of World Population: Unleashing the Potential of Urban Growth.

UNEP (2012). Global Initiative for Resource Efficient Cities. Paris: UNEP Division of Technology.

United Nations (2009). The UN Population Prospects: 2008 Revision Population Database. New York.

US-China Cleantech (2012). http://uschinacleantech.wordpress.com/

van Oort, F. (2004). City Growth and Innovation: Spatially Bounded Externalities in The Netherlands. Aldershot: Ashgate.

Wang, F., Sun, X., Reiner, D. M., \& Wu, M. (2020). Changing Trends of the Elasticity of China's Carbon Emission Intensity to Industry Structure and Energy Efficiency. Energy Economics, 86, Article ID: 104679. https://doi.org/10.1016/j.eneco.2020.104679

Wang, H., \& Wang, M. (2020). Effects of Technological Innovation on Energy Efficiency in China: Evidence from Dynamic Panel of 284 Cities. Science of the Total Environment, 709, Article ID: 136172. https://doi.org/10.1016/j.scitotenv.2019.136172

Wang, M., \& Feng, C. (2018). Using an Extended Logarithmic Mean Divisia Index Approach to Assess the Roles of Economic Factors on Industrial $\mathrm{CO}_{2}$ Emissions of China. Energy Economics, 76, 101-114. https://doi.org/10.1016/j.eneco.2018.10.008

Wang, Y., Cheng, Y., Yang, G. C. et al. (2018). Provincial Decomposition of China's Carbon Emission Rights under the Constraint of 2020 and 2030 Carbon Intensity Targets. China Environmental Science, 38, 3180-3188. (In Chinese)

Wang, Z., Zhu, Y., Zhu, Y., \& Shi, Y. (2016). Energy Structure Change and Carbon Emission Trends in China. Energy, 115, 369-377.

https://doi.org/10.1016/j.energy.2016.08.066

Wolde-Rufael, Y. (2005). Energy Demand and Economic Growth: The African Experience. Journal of Policy Modeling, 27, 891-903. https://doi.org/10.1016/j.jpolmod.2005.06.003

Wolfe, D. A., \& Bramwell, A. (2008). Innovation, Creativity and Governance: Social Dynamics of Economic Performance in City-Regions. Innovation: Organization \& Management, 10, 170-182. https://doi.org/10.5172/impp.453.10.2-3.170

World Bank (1997). China 2020: Development Challenges in the New Century. Washington DC: The World Bank.

World Economic Forum (2012). The Global Competitiveness Report 2011-2012. 
Wu, J., Wu, Y., Cheong, T. S., \& Yu, Y. (2018). Distribution Dynamics of Energy Intensity in Chinese Cities. Applied Energy, 211, 875-889.

https://doi.org/10.1016/j.apenergy.2017.10.097

Xie, L., Cheshmehzangi, A., Tan-Mullins, M., Flynn, A., \& Heath, T. (2020). Urban Entrepreneurialism and Sustainable Development: A Comparative Analysis of Chinese Eco-Developments. Journal of Urban Technology, 27, 3-26. https://doi.org/10.1080/10630732.2019.1680940

Xu, G., \& Wang, W. (2020). China's Energy Consumption in Construction and Building Sectors: An Outlook to 2100. Energy, 195, Article ID: 117045. https://doi.org/10.1016/j.energy.2020.117045

$\mathrm{Xu}$, H., Shwartz, P., \& Yang, H. (2020). Adjusting Energy Consumption Structure to Achieve China's $\mathrm{CO}_{2}$ Emissions Peak. Renewable and Sustainable Energy Reviews, 122, Article ID: 109737. https://doi.org/10.1016/j.rser.2020.109737

Yang, Z., Shao, S., Yang, L., \& Miao, Z. (2018). Improvement Pathway of Energy Consumption Structure in China's Industrial Sector: From the Perspective of Directed Technical Change. Energy Economics, 72, 166-176. https://doi.org/10.1016/j.eneco.2018.04.003

Ying, F., Jie, W., Yan, X. et al. (2016). How Will a Nationwide Carbon Market Affect Regional Economies and Efficiency of $\mathrm{CO}_{2}$ Emission Reduction in China? China Economic Review, 38, 151-166. https://doi.org/10.1016/j.chieco.2015.12.011

You, J. (2013). China's Challenge for Decarbonized Growth: Forecasts from Energy Demand Models. Journal of Policy Modeling, 35, 652-668. https://doi.org/10.1016/j.jpolmod.2012.03.003

Yuan, X.-C., Lyu, Y.-J., Wang, B., Liu, Q.-H., \& Wu, Q. (2018). China’s Energy Transition Strategy at the City Level: The Role of Renewable Energy. Journal of Cleaner Production, 205, 980-986. https://doi.org/10.1016/j.jclepro.2018.09.162

Yusuf, S., \& Saich, T. (2008). China Urbanizes: Consequence, Strategies \& Policies. Washington DC: The World Bank. https://doi.org/10.1596/978-0-8213-7211-1

Zhang, N., \& Zhou, M. (2020). The Inequality of City-Level Energy Efficiency for China. Journal of Environmental Management, 255, Article ID: 109843. https://doi.org/10.1016/j.jenvman.2019.109843

Zhang, X., Geng, Y., Shao, S., Wilson, J. M., Song, X., \& You, W. (2020). China's Non-Fossil Energy Development and Its $2030 \mathrm{CO}_{2}$ Reduction Targets: The Role of Urbanization. Applied Energy, 261, Article ID: 114353. https://doi.org/10.1016/j.apenergy.2019.114353

Zhou, L., Zhang, X. L., \& He, J. K. (2013). Main Problems and Suggestions on Local Decomposition of Carbon Intensity Targets in China. Science \& Technology Review, 31, 11. (In Chinese)

Zhou, X., Pan, Z., Shahbaz, M., \& Song, M. (2020). Directed Technological proGress Driven by Diversified Industrial Structrual Change. Structural Change and Economic Dynamics, 54, 112-129. https://doi.org/10.1016/j.strueco.2020.04.013

Zhu, J., \& Lin, B. (2020). Convergence Analysis of City-Level Energy Intensity in China. Energy Policy, 139, Article ID: 111357. https://doi.org/10.1016/j.enpol.2020.111357

Zhu, W., Zhang, Z., Li, X., Feng, W., \& Li, J. (2019). Assessing the Effects of Technological Progress on Energy Efficiency in the Construction Industry: A Case of China. Journal of Cleaner Production, 238, Article ID: 117908.

https://doi.org/10.1016/j.jclepro.2019.117908 